\title{
West Nile virus in overwintering mosquitoes, central Europe
}

\author{
Ivo Rudolf ${ }^{1,2}$, Lenka Betášová1, Hana Blažejová', Kristýna Venclíková ${ }^{1,3}$, Petra Straková ${ }^{1,2}$, Oldřich Šebesta ${ }^{1}$ \\ Jan Mendel ${ }^{1}$, Tamás Bakonyi ${ }^{4,5}$, Francis Schaffner ${ }^{6,7}$, Norbert Nowotny $^{5,8^{*}}$ (i) and Zdeněk Hubálek ${ }^{1,2}$
}

\begin{abstract}
Background: West Nile virus (WNV) is currently the most important mosquito-borne pathogen spreading in Europe. Data on overwintering of WNV in mosquitoes are crucial for understanding WNV circulation in Europe; nonetheless, such data were not available so far.
\end{abstract}

Results: A total of 28,287 hibernating mosquitoes [27,872 Culex pipiens, 73 Anopheles maculipennis (sensu lato), and 342 Culiseta annulata], caught in February or March between 2011 and 2017 in a WNV-endemic region of South Moravia, Czech Republic, were screened for the presence of WNV RNA. No WNV positive pools were found from 2011 to 2016, while lineage 2 WNV RNA was detected in three pools of Culex pipens mosquitoes collected in 2017 at two study sites.

Conclusions: To the best of our knowledge, this is the first record of WNV RNA in overwintering mosquitoes in Europe. The data support the hypothesis of WNV persistence in mosquitoes throughout the winter season in Europe.

Keywords: West Nile fever, West Nile virus, Flavivirus, Hibernation, Overwintering, Culex pipiens, Anopheles maculipennis, Culiseta annulata, Czech Republic

\section{Background}

West Nile virus (WNV) is a mosquito-borne virus (genus Flavivirus; family Flaviviridae) with nearly cosmopolitan distribution [1]. In nature, it circulates between birds (as amplifying hosts) and bird-feeding mosquitoes, in Europe predominantly Culex pipiens [2, 3]. Humans and horses are considered accidental dead-end hosts. In 2004 a neuroinvasive lineage 2 WNV (WNV-2) was discovered for the first time in Europe, i.e. in southeastern Hungary [4]. Since 2008, an unexpected explosive spread of this WNV-2 resulted in several hundreds of human and animal neuroinvasive cases in Hungary [5], Austria [5, 6], Greece [7, 8], Serbia [9], and Italy [10]. In the Czech Republic, four identical strains of WNV-2 were isolated from $C x$. modestus mosquitoes collected in reed beds at South-Moravian fishponds in 2013 [11].

\footnotetext{
* Correspondence: norbert.nowotny@mbru.ac.ae;

norbert.nowotny@vetmeduni.ac.at

${ }^{5}$ Institute of Virology, University of Veterinary Medicine, Vienna, Austria

${ }^{8}$ Department of Basic Medical Sciences, College of Medicine, Mohammed Bin

Rashid University of Medicine and Health Sciences, Dubai Healthcare City,

Dubai, United Arab Emirates

Full list of author information is available at the end of the article
}

Overwintering of the introduced WNV-2 in Europe was assumed (e.g. $[4,5]$ ), yet larger systematic studies which specifically focus on the persistence of WNV in overwintering mosquitoes are lacking in a European WNV endemic area. However, answering this question is crucial for the understanding of long-term persistence of WNV and the WNV epidemiology in general in Europe, especially in northern endemic regions. In contrast, in the United States, several such investigations were carried out, and WNV was occasionally detected in diapausing $C x$. pipiens, albeit at very low rates [12-15].

A long-term (seven-year) study was therefore undertaken to examine the prevalence of WNV in overwintering populations of mosquitoes collected from hibernacula located in a WNV endemic region in South Moravia. We performed molecular screening of female Cx. pipiens, Anopheles maculipennis (s.l.) and Culiseta annulata mosquitoes (they overwinter as nulliparous females) for WNV to evaluate the hypothesis of hibernation of WNV in overwintering mosquitoes in central Europe. 


\section{Methods}

\section{Study sites, mosquito collection and identification} Overwintering female mosquitoes were collected by battery-operated aspirators (Hausherr's Machine Works, Toms River, N.J. 08753, USA) from walls and ceilings of cellars including wine cellars, pensions, a water tower and a castle nearby WNV positive study sites [11]. Mosquito collections were carried out at localities Sedlec, Lednice, Hlohovec, Valtice and Břeclav in South Moravia always in February or March 2011 through 2017 (Table 1). Captured mosquitoes were transported in closed and chilled containers to the laboratory where they were identified on chilled tables under a stereomicroscope, using the determination key of Becker et al. [16] and then stored for further processing in freezers at $-60{ }^{\circ} \mathrm{C}$. Mosquitoes of the species $C x$. pipiens were not further analysed to discriminate between $\mathrm{f}$. pipiens and $\mathrm{f}$. molestus.

\section{Mosquito homogenization, RNA extraction, PCR analysis and sequencing}

Mosquito pools of usually 50 (1 to 100) females sorted by species, year and locality were prepared and homogenised in 1.5 to $2.0 \mathrm{ml}$ of cooled phosphate-buffered saline $\mathrm{pH} 7.4$ with $0.4 \%$ bovine serum albumin (fraction $\mathrm{V}$ ) and antibiotics. RNA was extracted from $150 \mu \mathrm{l}$ of cooled mosquito homogenates by using the QIAamp Viral RNA Mini Kit (Qiagen, Hilden, Germany), according to the manufacturer's instructions. The mosquito homogenates were tested by conventional reverse transcriptionpolymerase chain reaction (RT-PCR) for flaviviral RNA by using the protocol published by Scaramozzino et al. [17], and the Qiagen OneStep RT-PCR Kit (Qiagen) [18, 19]. Sequencing of PCR products and bioinformatic analyses were performed according to a previous study [20].

\section{Results}

A total of 27,872 female overwintering $C x$. pipiens in 573 pools, 73 An. maculipennis (s.l.) in 15 pools, and 342 Cs. annulata in 28 pools collected between 2011 and 2017 were tested for the presence of flavivirus RNA. All mosquito pools from 2011 to 2016 were negative, while in three $C x$. pipiens pools from 2017 WNV nucleic acid was demonstrated: in specimen 17-06 from Hlohovec collected on 27th February and in two samples from Lednice collected on 21st February (nos. 17-12 and 17-18). Sequencing of partial NS5 fragments (265 nt) of all three strains revealed the closest similarity to WNV strain 13-104 circulating in the area (97\% nucleotide identity) [11]. All three sequenced strains were identical to each other. A representative sequence was deposited in the GenBank database under the accession number MF162729. None of the pools was positive for Usutu virus, another important flavivirus which circulates in the region since 2012 [21] and causes epizootics in wild and domestic birds in Europe.

\section{Discussion}

WNV surveillance studies carried out periodically from 2006 through 2017 within the framework of European and national research projects comprising serological surveys of bird, horse and human populations for WNV neutralising antibodies as well as attempts to detect WNV in mosquitoes, horses and humans demonstrated limited WNV activity in the region [22, 23]. The only exception was repeated detection of WNV-2 in Cx. modestus and $C x$. pipiens mosquitoes in 2013 (minimum prevalence rate $0.012 \%), 2015(0.099 \%)$ and $2016(0.056 \%)$, respectively ([11, 20], unpublished data).

Regarding overwintering mosquitoes, one strain of WNV (strain 99-222, type Rabensburg) was isolated from $C x$. pipiens females collected in a mini fortress at Lanžhot on 13 October 1999, i.e. from mosquitoes commencing to overwinter [24]. Similarly in Lower Austria, close to places with diagnosed WNV-2 associated bird mortalities, three pools of adult female $C x$. pipiens mosquitoes caught during October 2008 in cellars proved positive for WNV-2 nucleic acid [5]. Vertical transmission of WNV was confirmed by detecting WNV-2 nucleic acid in one pool of $15 C x$. pipiens pupae as well as in a pool of two $C x$. pipiens egg rafts during a small-scale entomological survey carried out close to the home of a WNV-positive blood donor in Vienna [25].

Table 1 Study sites and number of overwintering mosquitoes collected in the Czech Republic, 2011 to 2017

\begin{tabular}{|c|c|c|c|c|c|c|c|c|c|c|c|c|c|c|c|c|c|c|c|c|c|}
\hline \multirow[t]{2}{*}{ Study site } & \multicolumn{3}{|l|}{2011} & \multicolumn{3}{|l|}{2012} & \multicolumn{3}{|l|}{2013} & \multicolumn{3}{|l|}{2014} & \multicolumn{3}{|l|}{2015} & \multicolumn{3}{|l|}{2016} & \multicolumn{3}{|l|}{2017} \\
\hline & C.p. & A.m. & C.a. & C.p. & A.m. & C.a. & C.p. & A.m. & C.a. & C.p. & A.m. & C.a. & C.p. & A.m. & C.a. & C.p. & A.m. & C.a. & C.p. & A.m. & C.a. \\
\hline Sedlec & 2250 & 0 & 0 & 1471 & 1 & 3 & 279 & 0 & 1 & 1132 & 0 & 4 & 1424 & 0 & 1 & 62 & 0 & 0 & 261 & 0 & 0 \\
\hline Lednice & 3714 & 7 & 175 & 1032 & 2 & 23 & 288 & 0 & 5 & 859 & 2 & 11 & 5187 & 11 & 44 & 446 & 7 & 1 & 732 & 15 & 6 \\
\hline Hlohovec & nd & nd & nd & nd & nd & nd & 1265 & 0 & 0 & 876 & 0 & 39 & 1441 & 0 & 6 & 528 & 0 & 1 & 166 & 0 & 0 \\
\hline Břeclav & 1252 & 26 & 2 & 160 & 0 & 2 & nd & nd & nd & 198 & 1 & 17 & 2730 & 1 & 1 & 0 & 0 & 0 & 102 & 0 & 0 \\
\hline Valtice & 0 & 0 & 0 & 0 & 0 & 0 & 0 & 0 & 0 & 0 & 0 & 0 & 0 & 0 & 0 & 17 & 0 & 0 & nd & nd & nd \\
\hline Subtotal & 7216 & 33 & 177 & 2663 & 3 & 28 & 1832 & 0 & 6 & 3065 & 3 & 71 & 10,782 & 12 & 52 & 1053 & 7 & 2 & 1261 & 15 & 6 \\
\hline Total & 7426 & & & 2694 & & & 1838 & & & 3139 & & & 10,846 & & & 1062 & & & 1282 & & \\
\hline
\end{tabular}


Given the low WNV-2 endemicity in the Czech Republic until 2013 it is understandable that, at least during the winter periods 2011 to 2013, no WNV-positive hibernating mosquitoes were found. Persistent WNV infections in certain bird species (e.g. as recently demonstrated in an exotic avian species in human care [26]) may to a lesser extent also contribute to the circulation of the virus, either through mosquitoes or oral transmission to predatory birds. Nonetheless, the classical bird-mosquito cycle including vertical transmission in mosquitoes is likely to be the predominant biological cycle of WNV maintenance and transmission. It is worth mentioning that some individuals of the examined pools of $C x$. pipiens mosquitoes might belong to f. molestus, which is characterized by autogeny, stenogamy, anthropophily and facultative diapause [16]. Several publications (e.g. [5]) provide clear-cut genetic evidence that WNV strains, once introduced to central Europe, are maintained there and disperse to neighbouring regions.

\section{Conclusions}

For the first time, WNV was detected in overwintering mosquitoes in Europe. This finding supports the hypothesis of WNV persistence in mosquitoes throughout the winter season in Europe. As a consequence, it can be presumed that lineage $2 \mathrm{WNV}$ infection in Europe is sustained by the long-term persistence of the virus in mosquitoes followed by vertical transmission and by the maintenance of the mosquito-bird transmission cycle, without the necessity of virus re-introductions. However, further studies are needed to analyse in-depth mode of circulation, overwintering and vertical transmission of WNV in central Europe by monitoring overwintering mosquito species, resident bird and horse populations as well as humans.

\section{Acknowledgements}

Not applicable.

\section{Funding}

This study was funded by the EU grant FP7-261504 EDENext. The contents of this paper are the sole responsibility of the authors and do not necessarily reflect the views of the European Commission. We also thank the Czech Science Foundation (No. 16-20054S) for financial support. The funding bodies had no role in study design, collection, analysis, and interpretation of data and preparation of the manuscript.

\section{Availability of data and materials}

All data generated or analysed during this study are included in the article. A representative sequence generated during the study was deposited in the GenBank database under the accession number MF162729.

\section{Authors' contributions}

IR and ZH designed the study. $L B, H B, K V, P S$ and OS participated in the mosquito sampling and determination, $\mathrm{LB}, \mathrm{HB}, \mathrm{KV}, \mathrm{PS}$, OS carried out the laboratory analyses, TB and JM participated in sequence analysis and the acquisition of data, analysis and interpretation of results. IR, NN, ZH and FS drafted the manuscript. All authors read and approved the final manuscript.
Ethics approval and consent to participate

Not applicable.

\section{Consent for publication}

Not applicable.

Competing interests

The authors declare that they have no competing interests.

\section{Publisher's Note}

Springer Nature remains neutral with regard to jurisdictional claims in published maps and institutional affiliations.

\section{Author details}

'Institute of Vertebrate Biology, Czech Academy of Sciences, v.v.i, Brno, Czech Republic. ${ }^{2}$ Department of Experimental Biology, Masaryk University, Brno, Czech Republic. ${ }^{3}$ Institute of Macromolecular Chemistry, v.v.i., Czech Academy of Sciences, Praha, Czech Republic. ${ }^{4}$ Department of Microbiology and Infectious Diseases, University of Veterinary Medicine, Budapest, Hungary. ${ }^{5}$ Institute of Virology, University of Veterinary Medicine, Vienna, Austria. ${ }^{6}$ Francis Schaffner Consultancy, Riehen, Switzerland. ${ }^{7}$ National Centre for Vector Entomology, Institute of Parasitology, Vetsuisse Faculty, University of Zurich, Zurich, Switzerland. ${ }^{8}$ Department of Basic Medical Sciences, College of Medicine, Mohammed Bin Rashid University of Medicine and Health Sciences, Dubai Healthcare City, Dubai, United Arab Emirates.

Received: 21 June 2017 Accepted: 21 September 2017

Published online: 02 October 2017

\section{References}

1. Hubálek Z, Rudolf I, Nowotny N. Arboviruses pathogenic for domestic and wild animals. Adv Virus Res. 2014;89:201-75.

2. Hubálek Z, Halouzka J. West Nile fever - a reemerging mosquito-borne viral disease in Europe. Emerg Infect Dis. 1999;5:643-50.

3. Hubálek Z. European experience with the West Nile virus ecology and epidemiology: could it be relevant for the New World? Viral Immunol. 2000;13:415-26.

4. Bakonyi T, Ivanics E, Erdélyi K, Ursu K, Ferenczi E, Weissenböck H, Nowotny N. Lineage 1 and 2 strains of encephalitic West Nile virus, central Europe. Emerg Infect Dis. 2006;12:618-23.

5. Bakonyi T, Ferenczi E, Erdélyi K, Kutasi O, Csörgő T, Seidel B, et al. Explosive spread of a neuroinvasive lineage 2 West Nile virus in central Europe, 2008/2009. Vet Microbiol. 2013;165:61-70.

6. Wodak E, Richter S, Bagó Z, Revilla-Fernández S, Weissenböck H, Nowotny N, Winter P. Detection and molecular analysis of West Nile virus infections in birds of prey in the eastern part of Austria in 2008 and 2009. Vet Microbiol. 2011;149:358-66.

7. Papa A, Danis K, Baka A, Bakas A, Dougas G, Lytras T, et al. Ongoing outbreak of West Nile virus infections in humans in Greece, July-August 2010. Euro Surveill. 2010;15.

8. Papa A, Bakonyi T, Xanthopoulou K, Vázquez A, Tenorio A, Nowotny N. Genetic characterization of West Nile virus lineage 2, Greece, 2010. Emerg Infect Dis. 2011;17:920-2.

9. Popović N, Milošević B, Urošević A, Poluga J, Lavadinović L, Nedelijković J, et al. Outbreak of West Nile virus infection among humans in Serbia, August to October 2012. Euro Surveill. 2013;18:pii=20613.

10. Barzon L, Papa A, Lavezzo E, Franchin E, Pacenti M, Sinigaglia A, et al. Phylogenetic characterization of central/southern European lineage 2 West Nile virus: analysis of human outbreaks in Italy and Greece, 2013-2014. Clin Microbiol Infect. 2015;21:1122.e1-10.

11. Rudolf I, Bakonyi T, Šebesta O, Peško J, Venclíková K, Mendel J, et al. West Nile virus lineage 2 isolated from Culex modestus mosquitoes in the Czech Republic, 2013: expansion of the European WNV endemic area to the North? Euro Surveill. 2014;19:pii=20867.

12. Nasci RS, Savage HM, White DJ, Miller JR, Cropp BC, Godsey MS, et al. West Nile virus in overwintering Culex mosquitoes, New York City, 2000. Emerg Infect Dis. 2001;7:1-3.

13. Bugbee LM, Forte LR. The discovery of West Nile virus in overwintering Culex pipiens (Diptera: Culicidae) mosquitoes in Lehigh County, Pennsylvania. J Am Mosq Control Assoc. 2004;20:326-7. 
14. Farajollahi A, Crans WJ, Bryant P, Wolf B, Burkhalter KL, Godsey MS, et al. Detection of West Nile viral RNA from overwintering pool of Culex pipiens pipiens (Diptera: Culicidae) in New Jersey. J Med Entomol. 2005;42:490-4.

15. Andreadis TG, Armstrong PM, Bajwa WI. Studies on hibernating populations of Culex pipiens from a West Nile virus endemic focus in New York City: parity rates and isolation of West Nile virus. J Am Mosq Contr Assoc. 2010;26:257-64

16. Becker N, Petrič D, Zgomba M, Boase C, Madon M, Dahl C. Mosquitoes and their control. 2010; 2nd ed. Heidelberg: Springer.

17. Scaramozzino N, Crance JM, Jouan A, DeBriel DA, Stoll F, Garin D. Comparison of flavivirus universal primer pairs and development of a rapid, highly sensitive heminested reverse transcription-PCR assay for detection of flaviviruses targeted to a conserved region of the NS5 gene sequences. J Clin Microbiol. 2001;39:1922-7.

18. Hubálek Z, Rudolf I, Bakonyi T, Kazdová K, Halouzka J, Sebesta O, Sikutová S, Juricová Z, Nowotny N. Mosquito (Diptera: Culicidae) surveillance for arboviruses in an area endemic for West Nile (Lineage Rabensburg) and Tahyna viruses in Central Europe. J Med Entomol. 2010;47:466-72.

19. Bakonyi T, Hubálek Z, Rudolf I, Nowotny N. Novel flavivirus or new lineage of West Nile virus, central Europe. Emerg Infect Dis. 2005;11:225-31.

20. Rudolf I, Bakonyi T, Šebesta O, Mendel J, Peško J, Betášová L, et al. Cocirculation of Usutu virus and West Nile virus in a reed bed ecosystem. Parasit Vectors. 2015;8:520.

21. Hubálek Z, Rudolf I, Čapek M, Bakonyi T, Betášová L, Nowotny N. Usutu virus in blackbirds (Turdus merula), Czech Republic, 2011-2012. Transbound Emerg Dis. 2014;61:273-6.

22. Hubálek Z, Halouzka J, Juřicová Z, Šikutová S, Rudolf I, Honza M, et al. Serologic survey of birds for West Nile flavivirus in southern Moravia (Czech Republic). Vector Borne Zoonotic Dis. 2008;8:659-66.

23. Straková P, Šikutová S, Jedličková P, Sitko J, Rudolf I, Hubálek Z. The common coot as sentinel species for the presence of West Nile and Usutu flaviviruses in Central Europe. Res Vet Sci. 2015;102:159-61.

24. Hubálek Z, Savage HM, Halouzka J, Juruicová Z, Sanogo YO, Lusk S. West Nile virus investigations in South Moravia. Czechland Viral Immunol. 2000;13:427-33.

25. Kolodziejek J, Seidel B, Jungbauer C, Dimmel K, Kolodziejek M, Rudolf I, et al. West Nile virus positive blood donation and subsequent entomological investigation, Austria, 2014. PLoS One. 2015:10:e126381.

26. Bakonyi T, Gajdon GK, Schwing R, Vogl W, Häbich AC, Thaller D, et al. Chronic West Nile virus infection in Kea (Nestor notabilis). Vet Microbiol. 2016;183:135-9.

\section{Submit your next manuscript to BioMed Central and we will help you at every step:}

- We accept pre-submission inquiries

- Our selector tool helps you to find the most relevant journal

- We provide round the clock customer support

- Convenient online submission

- Thorough peer review

- Inclusion in PubMed and all major indexing services

- Maximum visibility for your research

Submit your manuscript at www.biomedcentral.com/submit

C) Biomed Central 